\title{
The Decline of Ptolemaic Elephant Hunting: An Analysis of the Contributory Factors
}

After the death of Alexander the Great in 323 his successors (diadochi) engaged in a series of internecine struggles to take control of the territory he had conquered. One of the most capable of these Ptolemy, the son of Lagus (later to become Ptolemy I Soter), took control of Egypt, initially as satrap (323-306), and subsequently as king (306-283/82). Over several decades Ptolemy was able to seize Coele-Syria, parts of Asia Minor, and achieved leadership of the League of Islanders in the Aegean. ${ }^{1}$ The battles between the successors were fought with sizable infantry and cavalry forces. However, one of the most notable and highly valued components of these military forces were battle-elephants.

Alexander had encountered these animals in a number of battles, including at Gaugamela in Mesopotamia (331) and at the Hydaspes (modern Jhelum River) in the Indus region (326). ${ }^{2}$ Despite the practical and logistical problems posed by these very large animals they made such an impression on Alexander that he established his own corps. ${ }^{3}$ These were later to be divided up among his successors, and in several instances changed hands through capture. ${ }^{4}$ Ptolemy I possibly took control of some or all of the elephants (up to forty?) which Perdiccas had employed in his failed invasion of Egypt (321), and he certainly captured forty-

\footnotetext{
${ }^{1}$ For the career of Ptolemy I Soter see, G. Hölbl, A History of the Ptolemaic Empire (London, 2001), 9-34. Note all dates mentioned are BC unless otherwise stated.

${ }^{2}$ Gaugamela - 15 elephants - Arr. Anab. 3.8.6; Hydaspes - 85 elephants - Curt. 8.13.6.

${ }^{3}$ Alexander already had 27 elephants when he left Babylon in $327 \mathrm{BC}$ - H. Scullard, The Elephant in the Greek and Roman World (London, 1974), 64-5.

${ }^{4}$ For a discussion of the distribution of Alexander's elephant corps see, J. Kistler, War Elephants (Lincoln, 2007), 47-53.
} 
three from Demetrius after the Battle of Gaza (312). ${ }^{5}$ However, Ptolemy I was not in a position to obtain more elephants directly from India unlike his contemporary Seleucus I Nicator who in 304/03 had acquired 500 as part of a negotiated settlement with the Indian king Chandragupta Maurya (Sandrocottus in Graeco-Roman sources). ${ }^{6}$ Therefore due to natural attrition and losses in warfare, Ptolemy I's corps of Indian elephants likely dwindled by the time Ptolemy II Philadelphus took power in 283 (co-ruler from 285). ${ }^{7}$

The increasingly hostile relations between the Ptolemaic and Seleucid empires, the latter controlling overland routes to the East, meant new sources had to be found. In consequence Ptolemy II sent explorers to investigate sources of elephants in East Africa, as would his successors Ptolemy III Euergetes (r. 246-222) and Ptolemy IV Philopator (r. 221204). ${ }^{8}$ A number of ports and bases were established on the Red Sea coast, expeditions of large numbers of men were sent out, and elephants were brought to Egypt on specially constructed ships known as elephant-carriers (elephantēgoi). These elephant hunting expeditions occurred,

\footnotetext{
${ }^{5}$ Diod. Sic. 18.33-36, 19.82.3-4, 19.84.4. If he did capture Perdiccas' elephants they do not appear to be used at the Battle of Gaza - V. Troncoso, 'The Diadochi and the Zoology of Kingship: The Elephants', in V. Troncoso and E. Anson (eds.), After Alexander: The Time of the Diadochi (323-281 BC) (Oxford, 2013), 258.

${ }^{6}$ Strabo 15.2.9; App. Syr. 55; Just. Epit. 15.4.21; see also Plut. Vit. Alex. 62.4.

${ }^{7}$ L. Casson, 'Ptolemy II and the Hunting of African Elephants', TAPA 123 (1993), 248; S. M. Burstein, 'Elephants for Ptolemy II: Ptolemaic Policy in Nubia in the Third Century BC', in P. McKechnie and P. Guillaume (eds.), Ptolemy II Philadelphus and his World (Leiden, 2008), 140.

${ }^{8}$ Casson (n. 7), 255, argues convincingly that Philadelphus should be given the credit for putting elephant hunting on a systematic basis. Contra Rostovtzeff and Fraser who respectively attribute this to Euergetes or Philopator see, P. Fraser, Ptolemaic Alexandria (Oxford, 1972), 179; M. Rostovtzeff, 'Zur Geschichte des Ost- und Südhandels im ptolemäisch-römischen Ägypten’, Arch. Pap. 4 (1908), 298-315. Note Agatharchides explicitly asserts Philadelphus was the first to seriously pursue elephant hunting - Agatharchides 1.1 = Phot. Cod. 250.1, 441b.
} 
intermittently, for about 100-150 years until during the course of the second century the Ptolemies abounded these efforts. ${ }^{9}$

The purpose of this article is to examine why Ptolemaic elephant hunting activities ceased during the course of the second century and to assess which factors are most responsible. There is no consensus on these issues, with several scholars proposing a number of causes, not all mutually exclusive. Some have argued that the poor performance of Ptolemy IV's Forest elephants at the Battle of Raphia (217) against the larger Indian elephants of Antiochus III (r. 222-187) discouraged further activity. ${ }^{10}$ However, Fraser argued precisely the opposite, claiming that Ptolemy V (r. 204-180) engaged in hunting expeditions on a more organised basis due to the need to replace the elephants lost. ${ }^{11}$ Another potential factor was the difficulties faced in the south, especially in connection to an uprising in the Thebiad under Ptolemy V (uprising 205-186), which is likely to have meant at least a temporary succession of elephant hunting activity. ${ }^{12}$ Casson noted that over-hunting in areas along the coastal regions compelled hunters in search of easier pickings to move further and further south along the Red Sea coast and Gulf of Aden. ${ }^{13}$ This process inevitably made such expeditions harder and more costly. Alternatively Sidebotham proposed that the Ptolemies ceased hunting elephants not because

\footnotetext{
${ }^{9}$ These activities could be disrupted by events such as a major rebellion in southern Egypt between 205-186 BC (discussed below).

${ }^{10}$ S. Burstein, Agatharchides of Cnidus On the Erythraean Sea (Cambridge, 1989), 10-11; contra Burstein (n. 7), $145-6$.

${ }^{11}$ Fraser (n. 8) 178-9.

${ }^{12}$ For problems in the south in this period see, J. Manning, The Last Pharaohs: Egypt under the Ptolemies, 30530 BC (Princeton, 2010), 17; also Burstein (n. 7), 141, 146.

${ }^{13}$ Casson (n. 7), 256.
} 
they had exhausted the accessible hunting grounds but because they had been able to establish an effective breeding programme in Egypt. ${ }^{14}$

The credibility of these positions and the strength of the evidence on which they are based will be analysed in the following sections. It is argued here that while the disadvantages faced by the smaller Forest elephants may have been apparent in the aftermath of the Battle of Raphia, their failure at this battle was not a pivotal factor. The Ptolemies still had to counter the fact that the Seleucids had a significant elephant corps around the late-third and first-half of the second century. The uprising in the south of Egypt would have significantly hindered Ptolemaic elephant hunting activity, but this was only a temporary factor. It is instead suggested that the most significant factors were the exhaustion of the hunting grounds in the coastal areas making the cost-benefit ratio unfavourable, coupled with the decline of the ability of the Seleucids to restock their elephant corps during the course of the second century. As for the idea of a successful Egyptian breeding programme, there appears to be little evidence to substantiate this.

\section{Ptolemaic Elephant Hunting: A Brief Survey}

It is not the intention here to provide an in-depth discussion of how the Ptolemies conducted their elephant hunts as a number scholars have produced useful surveys on this topic. ${ }^{15}$ Nevertheless, it is worthwhile providing a brief summary of these activities, not only because it may prove useful for the reader less familiar with this topic, but also because an appreciation

\footnotetext{
${ }^{14}$ S. Sidebotham, Roman Economic Policy in the Erythra Thalassa 30 B.C. - A.D. 217 (Leiden, 1986), 4.

${ }^{15}$ H. Kortenbeutel, Der ägyptische Süd und Osthandel in der Politik der Ptolemäer und römischen Kaiser (Diss., Berlin, 1931); Scullard (n. 3), 123-45; Casson (n. 7); Burstein (n. 7), 140-7.
} 
of the practicalities involved is informative for understanding why the Ptolemies ceased to capture live elephant.

The Ptolemies may have initially attempted to acquire elephants by engaging with the Kushite (Meroitic) Kingdom to the south of Egypt. Ptolemy II certainly fought a war in this region, and an inscription (no longer surviving) recorded in the Christian Topography of Cosmas Indicopleustes speaks of Ptolemy III having 'Trog[1]odytic' and 'Aithiopian' elephants in his army. ${ }^{16}$ A Greek graffito from Abu Simbul which refers to an Indos (a designation for a mahout rather than an ethnic appellation) may also imply this route was attempted. ${ }^{17}$ However, while it is possible that the reference to Aithiopian elephants may imply some acquisitions via an overland route, Burstein notes that the logistical problems and long distance to the nearest elephant hunting grounds (600 miles south of Aswan) made this route impractical. ${ }^{18}$ It could be that these Aithiopian elephants came from the interior of Sudan, but were brought to Egypt via the coast. Indeed, most of the evidence, limited as it is, suggests attention was mainly focused on the coastal regions of the Red Sea and later the Gulf of Aden.

In order to find the most suitable hunting grounds along the East African coast a number of explorers were sent out to reconnoitre the region, most notable among them Satyrus, Eumedes, and Simmias who entered the Gulf of Aden. ${ }^{19}$ As a result of these explorations numerous ports and hunting bases were set up, including Arsinoe (Gulf of Suez region),

\footnotetext{
${ }^{16}$ OGIS 54 lines 1-14; Cosmas Indic. Topogr. Christ. 2.140-142. For the Trogodytes who reside along stretches of territory near the Red Sea coast see, Strabo 16.4.4-5; Plin. HN 6.33-34.163-176.

${ }^{17}$ For the graffito see, A. Bernard and O. Masson, 'Les inscriptiones grecques d'Abou Simbel', Rev. Et. Grec. 70 (1957), 40; J. Desanges, 'Les chasseurs d'éléphants d'Abou-Simbel', in Actes du 92e Congrès national des sociétés savantes (Paris, 1970), 31-50; R. Mairs, 'Intersecting Identities in Hellenistic and Roman Egypt', in R. J. Dann and K. Exell (eds.), Egypt: Ancient Histories, Modern Archaeologies (New York, 2013), 15.

${ }^{18}$ Burstein (n. 7), 141-2; Hölbl (n. 1), 55-6.

${ }^{19}$ Satyrus - Strabo 16.4.5; Eumedes - Strabo 16.4.7; Simmias - Diod. Sic. 3.18.4.
} 
Philotera (?), Berenike (Cape of Ras Banas) and Ptolemais-of-the-Hunts (Baraka delta region). ${ }^{20}$ The parties sent out on these hunts would depart from Koptos (Qift) or Apollonpolis Magna (Edfu) in southern Egypt and cross the Eastern Desert in order to reach the major port of departure Berenike. While the Apollonpolis Magna route to Berenike was shorter, eight days compared to twelve days from Koptos, both routes may have been used. ${ }^{21}$ The archaeological evidence certainly attests to cairns (route markers) and fortified stations along the route from Apollonpolis Magna, while Strabo speaks of Ptolemy II cutting a route and building stations (most probably) from Koptos to Berenike; a recent survey suggests one of these stations, called Simiou (El-Laqeita), was set up by Simmias under Ptolemy III. ${ }^{22}$ These stations were necessary for collating water in cisterns, monitoring the routes, and protecting travellers, as attested by inscriptions from the Paneion (El-Kanais, c.30 miles from Edfu) which allude to the potential threat of the indigenous Trogodytes. ${ }^{23}$

${ }^{20}$ Arsinoe - Strabo 17.1.25, Plin. HN 6.33.167; Philoteras - Strabo 16.4.4-5; Berenike - Strabo 17.1.45, Plin. HN
6.33.167-8; Ptolemais-of-the-Hunts - Strabo 16.4.7. On these ports see, G. Cohen, The Hellenistic settlements in Syria, the Red Sea Basin, and North Africa (Berkeley, 2006); also, S. Sidebotham, M. Hense, and H. Nouwens, The Red Land (Cairo, 2008).

${ }^{21}$ Plin. HN 6.26.102 says the journey from Koptos to Berenike was twelve days, assuming an equivalent travelling speed from Apollonpolis Magna this would be eight to nine days. Average of 15-20 miles per day.

${ }^{22}$ For the route from Edfu see, H. Wright, 'Archaeological Survey in the Eastern Desert Conducted by the University of Michigan and the University of Assiut: Interim Report', in S. Herbert and A. Berlin (eds.), Excavations at Coptos (Qift) in Upper Egypt 1987-1992 (Rhode Island, 2003), 224-231. Strabo 17.1.45 - is ambiguous about whether the route was cut from Koptos but the context of the passage suggests this was the case. For the argument that Simiou was founded by Simmias see, A. Bülow-Jacobsen, 'Toponyms and Proskynemata', in H. Cuvigny (ed.), La route de Myos Hormos (Cairo, 2006), 51-9.

${ }^{23}$ Cohen (n. 20), 324 n.6; A. Bernard, Pan du désert (Leiden, 1977). For problems with indigenous populations later in the Roman period see, H. Cuvigny, Ostraca de Krokodilô (Cairo, 2005). 
Having crossed the Eastern Desert and sailed down the Red Sea these hunting parties, which could be a few hundred men strong, would start operating from their bases. ${ }^{24}$ Among these parties were not only the hunters, but trainers, mahouts (elephant-drivers) and also tame elephants. There is no direct testimony of the methods used by hunting parties in East Africa, but there are accounts from Megasthenes (pertaining to India) and Juba (North Africa) which survived in other sources. Casson is very likely correct to suppose that the Ptolemies employed methods similar to those described by Megasthenes. ${ }^{25}$ This entailed creating a corral, using tame female elephants to encourage wild males to cross over the temporary bridge and then trapping them. After the wild elephants became worn down from deprivation, riders entered with other tame elephants and after a brief battle subdued the wild ones.

The captured elephants, after a period of taming, were coaxed onto the elephantēgoi for the return voyage to Berenike. These sail vessels, which were wide with a low draft, used the prevailing southerlies between October and May to help them sail northward. Benches for oarsmen were not included due to the space this would have taken up. ${ }^{26}$ The voyage could be dangerous with the potential for vessels to get trapped on rocks or sandbanks. ${ }^{27}$ Assuming the vessels made it safely, the elephants would have been temporarily corralled at Berenike before their journey across the Eastern Desert. ${ }^{28}$ This was to be followed by journeys up the Nile, most likely to a major base at Memphis. ${ }^{29}$

\footnotetext{
${ }^{24}$ One document mentions an expeditionary party of 231 men -W.Chr. 451; Casson (n. 7), 252.

${ }^{25}$ Megasthenes - Arr. Indica 13-14; Juba - Plin. HN 8.8.25; Casson (n. 7), 249.

${ }^{26}$ Casson (n. 7), 251-3; S. Sidebotham, Berenike and the Ancient Maritime Spice Route (London, 2011$), 8$.

${ }^{27}$ Agatharchides 85a = Phot. Cod. 250.83, 456b-457a, Agatharchides 5.85b = Diod. Sic. 3.40.5.

${ }^{28} \mathrm{~A}$ ' $\mathrm{V}$ '-shaped ditch has been found at Berenike which the excavators have interpreted as a potential elephant corral - Sidebotham, Hense, and Nouwens (n. 20), 162.
}

${ }^{29}$ P.Petr. II 20 col. iv; Casson (n. 7), 258-9. 


\section{The decline of elephant hunting: causal factors}

Clearly the investment required by the Ptolemies to obtain elephants was substantial, including the upkeep of stations in the Eastern Desert, ports and bases, specialised shipping, as well as the cost of supplying and paying those engaged in these expeditions. ${ }^{30}$ The desirability, practicality and cost of such efforts will all have impacted on the choice or ability of the Ptolemies to continue these efforts.

\section{Battle of Raphia (217) and rivalry with the Seleucids}

Polybius reports that during the Battle of Raphia Ptolemy IV's 73 elephants, most, if not all of which were African (Forest) elephants, were not sufficient to withstand the 102 Indian elephants of Antiochus III. ${ }^{31}$ It is said that the African elephants could not endure the smell,

\footnotetext{
${ }^{30}$ One document from 223 indicates that the average monthly pay was twenty drachmas, a comparatively high wage rate - W.Chr. 451; see also W.Chr. 452; Casson (n. 7), 252.

${ }^{31}$ African Bush elephants (Loxodonta africana) are in fact larger than Indian elephants (Elephas maximus), but Forest elephants (Loxodonta cyclotis), who are related to the former, are smaller than both. Most recent scholars assume that the African elephants must be the smaller Forest (not Bush) elephants because the ancient authors repeatedly refer to them being smaller than Indian elephants - Casson (n. 7), 248; M. Charles, 'African Forest Elephants and Turrets in the Ancient World', Phoenix 62 (2008), 338-9. Charles has proposed that some of Ptolemy's 73 elephants may have been Indians ones previously captured from the Seleucids, and these were the few brave ones who to put up a fight against Antiochus' elephants - M. Charles, 'Elephants at Raphia: Reinterpreting Polybius 5.84-5', CQ 57.1 (2007), 306-11. This is possible, since the aforementioned inscription of Ptolemy III mentions the capture of Indian elephants from the Seleucids, though this event predates the Battle
} 
trumpeting, larger size and strength of the Indian elephants and caused havoc by fleeing back into the Ptolemaic line. In the end Ptolemy IV won the battle, but in spite of his elephant corps. On first impression it might seem reasonable to suppose the Ptolemies would abandoned difficult and costly elephant hunts given such poor results. ${ }^{32}$

However, it is likely that the Ptolemies felt compelled to restore their elephant corps as Fraser suggests. ${ }^{33}$ This is because the Seleucids in the latter-third and first-half of the second century still had a significant elephant corps to be countered. About a decade after the Battle of Raphia Antiochus III marched to the East in order to deal with revolts in Hyrcania-Parthia and Bactria. ${ }^{34} \mathrm{He}$ had mixed success, but one of the outcomes was that he acquired a number of elephants from the Graeco-Bactrian ruler Euthydemus, and subsequently renewed an alliance with the (Mauryan?) king Sophagasenus in which he received more elephants - in total his corps now reached 150 . Taking natural attrition into account, this force must, nevertheless, have proved a potential threat to the Ptolemies for a few decades. ${ }^{35}$

Antiochus III's successors do seem to have been in a position to acquire more elephants from India, although this must have become increasingly difficult. Bactria had not only confirmed its independence, but under Euthydemus and his successor Demetrius their territory expanded into Arachosia (along the Arghandab valley), and possibly into the Indus area and

of Raphia by 25-30 years so it is likely that only a portion were still battle-worthy or living by the this time. For the inscription's date see, G. W. Bowersock, The Throne of Adulis (Oxford, 2013), 41.

${ }^{32}$ Polyb. 5.79-84; Burstein (n. 10).

${ }^{33}$ Fraser (n. 8), 179.

${ }^{34}$ Polyb. 10.49, 11.34; Just. Epit. 41.4.

${ }^{35}$ Elephant life spans parallel those of humans - Casson (n. 7), 250 n.12. 
Gujarat. ${ }^{36}$ Subsequent Graeco-Bactrian kings certainly went on to conquer south of the Hindu Kush and acquire territories formerly controlled by the Maurya in the northwest (the last Mauryan king was assassinated by Pushyamitra Sunga in 180s). ${ }^{37}$ To further add to Seleucid woes, the Parthians continued to expand westwards at their expense. ${ }^{38}$ As time progressed it is likely that the Seleucids found it harder and harder to acquire elephants from India, and by the mid-late second century it is likely they were likely completely cut off. ${ }^{39}$

Notwithstanding the increasing difficulties, Antiochus IV (r. 175-164) did have an active elephant corps. This was in spite of the Treaty of Apamea (188) in which the Romans required Antiochus III to surrender his elephants and forbid the Seleucids from using them in the future. ${ }^{40}$ In the First Maccabees Antiochus IV is said to have invaded Egypt (169-68) with forces that included elephants. ${ }^{41} \mathrm{He}$ evidently had forty elephants in his grand process at Daphne in $166 .{ }^{42}$ The Third Maccabees would also claim that during the Jewish revolt (16760) Antiochus IV planned to use 500 elephants to crush them. This, however, seems an

\footnotetext{
${ }^{36}$ In a rather ambiguous passage of Strabo (11.11.1) it is reported that Demetrius the son of Euthydemus (or at least one of the Graeco-Bactrian kings) took possession of Saraostos (Surashthra?) and Sigerdis (Kutch?) in Gujarat, and Patalena (Indus River mouth) in southern Pakistan.

${ }^{37}$ On the Graeco-Bactrians, see H. Sidky, The Greek Kingdom of Bactria: (UPA, 2000); also R. Mair, The Hellenistic Far East (Oakland, 2014). For discussion of the Maurya see, R. Thapar, Asoka and the Decline of the Mauryas: Third Edition (Oxford, 2012).

${ }^{38}$ On the Parthians see, M. Colledge, The Parthians (London, 1976).

${ }^{39}$ Scullard (n. 3), 135.

${ }^{40}$ Polyb. 21.42.12; Hölbl (n. 1), 145. Possibly this was not enforced until 163 or 162 when Gnaeus Octavius hamstrung the elephants at Apamea - Polyb. 31.2.11; App. Syr. 46; A. Kuhrt and S. Sherwin-White, From Samarkhand to Sardis (Oakland, 1993), 215. Alternatively it has been suggested that new elephant were acquired, N. Sekunda, Seleucid and Ptolemaic Reformed Armies 168-145 BC (Stockport, 1994), 27-8.

${ }^{41}$ I. Macc. 1.17.

${ }^{42}$ Polyb. 30.25.11.
} 
implausibly high number, and the figure in the Second Maccabees of 80 elephants being used against the Jewish rebels at Bethsuron (164) sounds more credible. ${ }^{43}$

It is not impossible that some elephants had been successfully breed in captivity, but there is little evidence to substantiate this idea. ${ }^{44}$ It may be more plausible to suppose that at least prior to the 150-40s, when the Parthians took control of Media, Mesopotamia and Babylonia, that the Seleucids were able to diplomatically acquire Indian elephants from some of the Graeco-Bactrian/Indo-Greek kings. ${ }^{45}$ After this period, however, they clearly could not. Indeed, the only later literary reference to the Seleucid's acquiring elephants is when Ptolemy VI Philometor died in Syria (145) and his force of Forest elephants were seized by Demetrius II, a contender for the Seleucid throne. ${ }^{46}$ In consequence by the mid-late second century the Ptolemies may no longer have felt the same imperative to counter the Seleucids by keeping up their elephant hunting efforts which, as will be shown, became increasingly more difficult.

The Great Revolt of the Egyptians (205-186 BC)

There have been various suggestions about the specific catalysts and longer term tensions which caused a major rebellion in the south of Egypt between 205-186, including cultural

\footnotetext{
${ }^{43}$ II. Macc. 11.5; Scullard (n. 3), 186.

${ }^{44}$ Contrary to Sekunda's claim, followed by Kistler, Strabo does not state that there was an elephant breeding ground at Apamea, but in fact only for horses - Strabo 16.2.10; Sekunda (n. 40), 27-8; Kistler (n. 4 ), 69.

${ }^{45}$ See Colledge (n. 38); Scullard (n. 3), 186. The Graeco-Bactrians were already losing territory to nomadic invaders around this time. Samarkand was sacked c.145-130 and Aï Khanum c.145 - Strabo 11.8.2; Fan Ye Hou Han Shu 88.13-14; C. Rapin 'Nomads and the Shaping of Central Asia: from the Early Iron Age to the Kushan Period', in J. Cribb and G. Herrmann (eds.), After Alexander: Central Asia before Islam (London, 2007), 29-72. 46 Joseph. AJ 13.4.8-9; Scullard (n. 3), 188-9. Antiochus VII used ten of these Forest elephants against the Parthians in 130, after which there is no further record of their use by the Seleucids - Kistler (n. 4), 154-5.
} 
chauvinism by the immigrant Graeco-Macedonian population, alienation of some of the Egyptian elite, and the arming and training a significant body of Egyptians in Macedonian style warfare prior to the Battle of Raphia. ${ }^{47}$ Whatever the causes, the consequence was that for around two decades the Ptolemies were cut off from the important sites of Koptos and Apollonpolis Magna the starting points for the routes leading to the port of Berenike. This likely prohibited elephant hunting activities until access to the south was restored.

The Ptolemies did possess ports in the north of the Red Sea, most notably Arsinoe in the Gulf of Suez. This port may even have been temporarily connected to the Nile by a canal (along the Wadi Tumilat), established in the Persian period, if not earlier, and which was restored by Ptolemy II. ${ }^{48}$ However, these northerly ports were not a viable means by which the Ptolemies could bring elephants back to Egypt. The elephantēgoi, which relied on sails and not oars, would have found it extremely difficult to beat against the prevailing northerlies which dominate the uppermost part of the Red Sea. ${ }^{49}$ The problem with fighting against the winds in the Red Sea is demonstrated by a later Roman period document dating to June AD 97 which mentions a group of merchant ships (who had clearly arrived a few months late) perilously struggling for five hours to enter the safety of the harbour at Berenike. ${ }^{50}$

\footnotetext{
47 J. Adler, 'Governance in Ptolemaic Egypt: From Raphia to Cleopatra VII (217-31 B.C.), Class-based 'Colonialism'?', Akroterion 50 (2005), 27-38; Manning (n. 12), 17.

${ }^{48}$ Arist. Mete. 1.14.20-8; Strabo 17.1.25-6; Plin. HN 6.33.165; Hdt. 2.158-9; Diod. Sic. 1.33.7-12; Cohen (n. 20), 308; Sidebotham (n. 26), 19; Burstein (n. 7), 143.

${ }^{49}$ L. Casson, 'Rome's Trade with the East: The Sea Voyage to Africa and India', TAPA 110 (1980), 21-36; J. Whitewright, 'How Fast is Fast? Technology, Trade and Speed under Sail in the Roman Red Sea', in I. Starkey, P. Starkey, and T. Wilkinson (eds.), Natural Resources and Cultural Connections of the Red Sea (Oxford, 2007), $77-87$.
}

${ }^{50}$ P.CtYBR inv. 624 - See M. Peppard, 'A Letter Concerning Boats in Berenike and Trade on the Red Sea', ZPE 171 (2009), 193-8. 
Burstein regards this two decade rebellion as being largely responsible for the decline in Ptolemaic elephant hunting activities, though he does note that Ptolemy VI may temporarily have resumed elephant hunting since he possessed number of them during his invasion of Syria. It is suggested that this programme was aborted in 145, the year of Ptolemy VI's death. ${ }^{51}$ Given the significant numbers of elephants that Antiochus IV possessed it seems very likely that the Ptolemies desired to restore their elephant corps to strength, at least in the two decades after the Great Revolt of the Egyptians.

\section{Exhaustion of Elephant Hunting Grounds}

The factor which is arguably most significant in causing a decline in Ptolemaic elephant hunting is the exhaustion of the more easily accessible coastal hunting grounds. As Casson noted, the constant southward advancement of hunting bases down the Red Sea coast and into the Gulf of Aden clearly ties into the need to find fresh hunting grounds. Rather than attempting to venture too far into the interior, it seems these hunting parties found it easier to abandon earlier bases (though some survived as places for commerce) in search of easier pickings further down the coast. ${ }^{52}$ The increasing distances of these bases, however, inevitably increased the practical and logistical problems in such undertakings.

The exhaustion of coastal hunting grounds may even have had a long term ecological impact. In the mid-first century AD Pliny the Elder would claim that it was difficult to acquire ivory in large quantities outside of India. ${ }^{53}$ In addition the unknown author of the Periplus Maris Rubri (or Periplus Maris Erythraei), a merchant's guide to the major ports of the western

\footnotetext{
${ }^{51}$ Burstein (n. 7), 145-6.

${ }^{52}$ Casson (n. 7), 256; Ptolemais-of-the-Hunts continued to act as a commercial port - Peripl. M. Rubr. 3.

${ }^{53}$ Pliny $H N$ 8.4.7.
} 
Indian Ocean (c.AD 40-70), reports that ivory was only available in limited quantities along the coast of East Africa until one rounded Cape Guardafui and came to Rhapta (on the coast of Tanzania). ${ }^{54}$ It is worth noting that the Ptolemies did not simply captured live elephants but were also involved in the ivory trade. Indeed, Burstein has argued that hunting for ivory, played an additional, and probably more substantive role, in denuding the elephant populations in Northeast Africa. ${ }^{55}$ It is quite possible that this Ptolemaic acquisition of ivory and its sale in Mediterranean markets is reflected in apparent price slumps during the third century. This claim has been made on the basis of three temple inscriptions on the island of Delos which record the cost of ivory at different dates $(279-8$ drachmae a mina; $276-5$ drachmae per mina; $250-3.5$ drachmae per mina). ${ }^{56}$

It is not suggested that the Ptolemies completely wiped-out the coastal elephant populations along the the Red Sea and Gulf of Aden, and it must be acknowledged that there is roughly two centuries between the cessation of elephant hunting by the Ptolemies and the accounts of the Periplus and Pliny. Nevertheless, it would be a mistake to disregard the ecological impact of a century or more of sustained elephant hunting (both for live elephants

\footnotetext{
${ }^{54}$ Peripl. M. Rubr. 3, 6, 7, 10, 16-17 - Ptolemais-of-the-Hunts (Sudan)-occasionally a little ivory (likewise Adulis); Barbaria (Zoskales kingdom) - ivory, and weapons for hunting; Avalites (Ethiopia?) - a little ivory; Mosyllon (probably Ras Filuch) - ivory on rare occasions; at Rhapta (Dar es Salaam) - a great amount of ivory. ${ }^{55}$ S. M. Burstein, 'Ivory and Ptolemaic Exploration of the Red Sea: The Missing Factor', Topoi 6.2 (1996), 799807.
}

${ }^{56}$ IG XI 2163Aa7, 203A71, 287A118; D. Rathbone, 'The 'Muziris' Papyrus (SB XVIII 13167): Financing Roman Trade with India', in S. Abd-El-Ghani and W. Farag (eds.), Alexandrian Studies in Honour of Mostafa el Abbadi (Alexandria, 2000), 39-50; Sidebotham, Hense, and Nouwens (n. 20), 162-4; Burstein (n. 55), 803-4. See also Reger who argues that other factors beyond supply may have contributed to the prices recorded - G. Reger, 'The Price Histories of some Imported Goods on Independent Delos', in W. Scheidel and S. von Reden (eds.), The Ancient Economy (Edinburgh, 2002), 133-54. 
and the acquisition of ivory) by the Ptolemies. Moreover, they were the only party involved. Agatharchides certainly reported on various indigenous groups who hunted and ate elephants, although some of the method by which they are reported to have done so appear slightly fanciful. ${ }^{57}$ The kingdom of Meroe almost certainly impacted on the elephant populations of Sudan due to the ivory trade and the acquisition of elephants for warfare. This is apparent from their frequent representations in art, most notably the image of a Meroitic king riding an elephant at Musaw-warat es-Sofra. There is also possible evidence for an elephant pen and training grounds at this site, which if correct compliments Arrian's claim that the Indians and the Ethiopians were already employing war-elephants before the Macedonians, Carthaginians and Romans. ${ }^{58}$ These activities by the Ptolemies and others made it increasingly difficult and expensive to obtain live elephants and this was almost certainly a major factor leading to the cessation of Ptolemaic elephant hunting.

\section{Breeding Elephants in Egypt}

The last factor to be considered is the possibilty of a successful elephant breeding programme in Egypt. Sidebotham had proposed this idea in his work Roman Economic Policy in the Erythra Thalassa. He questioned the idea that the Ptolemies would cease to hunt elephants because the Seleucids could no longer get access to them, and suggested that if they were regarded as such an important military asset surely the Ptolemies would want to gain a military

\footnotetext{
${ }^{57}$ Agatharchides fragments 54a and b, 55a, 56a and b - for these see Burstein (n. 10).

${ }^{58}$ Arr. Tact. 2.2. Stockpiles of ivory found at the palace of Wad ben Naqa also allude to elephant hunting activities - P. L. Shinnie, Meroe: A Civilization of Sudan (London, 1967), 94-5, 100, 111; D. A. Welsby, The Kingdom of Kush: The Napatan and Meroitic Empires (London, 1996), 43, 124, 146-7, 175-6; R. Haaland, 'The Meroitic Empire: Trade and Cultural Influences in an Indian Ocean Context', Afr Archaeol Rev 31 (2014), 649-73.
} 
advantage. It is claimed that enough elephants had been brought to Egypt during the reign of Ptolemy IV that a supply could be maintained from domestic breeding. ${ }^{59}$

Sidebotham is probably correct to assume that the Ptolemies would not throw away a military advantage if they could maintain it, which is likely why Ptolemy VI had an elephant corps when he invaded Syria in 145. However, as has been noted in the preceding section, maintaining hunting expeditions seems to have become increasingly difficult due to the overhunting. Sidebotham is not able to offer any supporting evidence for a breeding programme. Indeed, ancient authors commented upon the supposed modesty of elephants who it is claimed only mated secretly in the privacy of the forest. ${ }^{60}$ Projections of anthropomorphised emotions aside, while elephants can actually be breed in captivity, it is with great difficulty and at a slower pace. ${ }^{61}$ In fact, modern zoos have found great difficulty in sustaining populations of both captive African and Indian elephants because they breed poorly or not at all. ${ }^{62}$ In light of the absence of supporting ancient evidence and the difficulties of breeding captive elephants as attested by modern zoological research, it seems reasonable to reject the idea that Ptolemies ceased hunting them due to a successful breeding programme.

\section{Conclusion}

The most important factor which caused a decline in Ptolemaic elephant hunting was the increasing exhaution of more easily accessible hunting grounds along the African coast of the

\footnotetext{
${ }^{59}$ Sidebotham (n. 14), 4.

${ }^{60}$ Plin. HN 8.5.13; Ael. NA 8.17; cf. Arist. Hist. an. 578a18; Scullard (n. 3), 44, 212.

${ }^{61}$ Casson (n. 7), 251 n.13; Burstein (n. 7), 145; Kistler (n. 4), 68-9.

62 See the Elephant Reproduction Project of the Smithsonian Conservation Biology Institute https://nationalzoo.si.edu/SCBI/ReproductiveScience/ElephantBreedRepro/, accessed 27 November 2015.
} 
Red Sea and Gulf of Aden. Another contributory factor was that by the mid-late second century the Seleucids could no longer access Indian elephants from the East. The Ptolemies may have wished to initially maintain an advantage, but with the mounting difficulties and expenses of acquiring them, coupled with the fact that there was no longer the same imperative to counter the Seleucid elephants on the battlefield, it must have been no longer worth the effort. There is no substative evidence to indicate that the Ptolemies successfully implemented a breeding programme in Egypt, so this idea should be discounted. 